\title{
Influence of School Based Policies on Internal Efficiency in Public Day Secondary Schools in Nyatike Sub County, Kenya
}

\author{
Khatete Ibrahim* \\ Department of Educational Administration and Planning, University of Nairobi, Kenya \\ *Corresponding author: ib2khatete6@gmail.com
}

\begin{abstract}
Policies formed at the school level have tended to interfere with national agenda universal schooling in many countries of the world. A study therefore was carried out on the influence of school-based policies on internal efficiency in public day secondary schools in Nyatike Sub County, Kenya. The study was guided by three objectives; students' grade to grade promotion policy, schools time management policy and school time tabling. The design employed in this study was descriptive survey. The researcher targeted all 52 secondary schools in Nyatike sub-county. Stratified random sampling was used to arrive at the chosen samples for the study. The school-based policies analyzed were found to affect the internal efficiency in education in public secondary schools. The government's policy of no repetition, was found be flowed by all the schools as they had their own students' grade to grade promotion policy based on students' performance in internal examinations. All schools visited were found to be using exams for promotions. Ninety point zero three percent of the students responded that rules put by schools on student grade to grade affects their wellbeing and stay in school. Sixty one point five three percent of the students sampled believed student grade to grade policy has an impact on repetition of students. On time management policy, a majority of the schools did not have strategic plans to guide the operations in schools. However, the schools had timetables as required by the ministry of education. No effort was put in place to assist weak students in bettering in their academics to meet the set school targets for promotion. In conclusion the internal school policies on grade to grade promotion have affected greatly the internal efficiency in education in Nyatike sub-county. The inefficiency index of 1.3 was found. There is poor implantation of time management policy and there is a lot of waste of time in the afternoons in the sub-county. It is recommended that close monitoring be done by the sub-county director of education office on implementation of no student repetition policy.
\end{abstract}

Keywords: terms used, academic performance, automatic promotion, internal efficiency, students' grade to grade promotion policies, time management policy

Cite This Article: Khatete I., "Influence of School Based Policies on Internal Efficiency in Public Day Secondary Schools in Nyatike Sub County, Kenya." American Journal of Educational Research, vol. 6, no. 3 (2018): 161-169. doi: 10.12691/education-6-3-1.

\section{Background to the Study}

Education remains a single most important investment that can propel countries to achieve or hasten their economic growth [1]. Education is a recipe that aids in the development of an individual according to his needs and demands of society, of which he is an integral part. No country has achieved meaningful economic development without considerable investment in human capital through education [2]. As a consequence governments and private enterprises devote huge investments in education sector. This is mainly to counter consequences of low education and uneducated society which is regarded as an obstacle to any nation's prosperity in all spheres of life. The society therefore benefits only if the population is encouraged and given the opportunity to have its children to learn and transit through the education system.
Investment into education is measured by the quality and adequacy of the inputs. Inputs in education refers to the elements such as teachers, administrators, students, educational materials, buildings, and various equipments that are necessary for the proper functioning of a teaching/learning process in a school. These inputs would affect internal efficiency in education. Internal efficiency is defined as the amount of learning achieved during the school age attendance, compared to the resources availed to support education [3]. Effectively, it measures the performance of the education system as indicated by students successfully transiting from one grade or level to another through the education system without wastage.

Student flow analysis method is based on three activities that happen in education school cycle: students may be promoted to next grade or level, may repeat the grade or level and they may drop out from the school system permanently. Therefore, indicators of internal efficiency include performance rates, dropout rates, 
promotion rates and repetition rates. Most of these indicators are observed within the school system. Consequently, the student grade to grade promotion policies within the schools, teaching and learning resources available, school time management policy, and school physical infrastructure can have great bearing on internal efficiency in the education system.

Whereas wastage in education in Migori has been blamed on the parents as expressed by the County Education Board during one of its meetings, schools themselves are not free from blame. The county is faced with economic hardships experienced by the locals due to lack of economic investment and perennial challenges of floods leaving the soil acidic and completely leached for any agricultural productions. It is however expected that schools should counter the challenges of poverty to keep students in school to learn by using government resources under free primary and free day secondary tuition fee arrangements. The schools in the county however are faced with rigid student grade to grade promotion policies as school heads and managers fight for good school and subject mean grades and scores, lack of teaching and learning resources within schools as a result of inadequate government and public funding, lack of school physical facilities like science laboratories, classrooms and latrines and none completion of school syllabi arising from confusion on the interpretation of the teaching time table policy.

Nyatike sub-county borders Lake Victoria and suffers serious drawbacks of flooding. The sub-county comprises of Muhuru division, Kaler division, Kachola division, Nyatike division and Karungu division. The sub-county is the poorest among other sub-counties with the only economic activities as fishing and illegal gold mining which take serious tolls on the school going children especially boys. These activities have had dire consequences to the sub-county in terms of children's school attendance. The statistics from the sub-county education office indicate serious wastage in education due to repetition and dropouts. The data from Nyatike education office shows that the dropout rate has been high especially from schools neighboring the lake and in gold mining regions. The dropout rate is reported to be at 29 percent in Muhuru division, 26 percent in Kaler division, 21 percent in Kachola division, 19 percent in Nyatike division and 18 percent in Karungu division. It is against this background that a research into school factors especially the school based policies influencing internal efficiency were done.

\subsection{Purpose of the Study}

The purpose of the study was to investigate the influence of school based factors on internal efficiency in mixed public secondary schools in Nyatike Sub County.

\subsection{Objectives of the Study}

This study was to address the following objectives;

(i) To determine the extent to which schools' students' grade to grade promotion policy influence the internal efficiency in mixed public secondary schools in Nyatike Sub County

(ii) To establish the influence of schools' time management policy on the internal efficiency in mixed public secondary schools

(iii) To examine the influence of the implementation of teaching time table policy on the internal efficiency in mixed secondary schools

\subsection{Research Questions}

This study was guided by the following questions;

(i) To what extent does schools' students' grade to grade promotion policies influence the internal efficiency in mixed public secondary schools in Nyatike Sub County

(ii) How does the schools' time management policy influence the internal efficiency in mixed public secondary schools?

(iii) What is the effect of implementation of school teaching timetable policy on the internal efficiency in mixed public secondary schools?

\subsection{Significance of the Study}

The findings of the study may provide useful guidelines to various stakeholders including policy makers, educationists, among others, on the best ways possible to address factors affecting internal efficiency in education system. The study findings may serve to provide school management with an insight in addressing the identified factors within the schools that affect the internal efficiency in education in the sub county if the current status is to be addressed. The findings tallied may also make additional contribution in generating knowledge to the existing literature and it may provide information to the scholars interested to conduct further research on the topic.

\subsection{Limitations of the Study}

Getting information from drop outs themselves would have been very vital but remained a biggest challenge in locating and convincing them to participate. This was found to be technical since they had already exited the schools where the research was being carried out. The challenge was mitigated by concentrating on students who were present in their various schools at the time of data collection with an assumption that the views they expressed would to those of those who dropped out since they live in the same environment being day scholars.

\subsection{Scope of the Study}

Delimitation of the research provides clear demarcations that ensure the topic under investigation is manageable [13]. The study only focused on mixed public secondary schools because these are the schools that accommodate students from the locality in the Sub County. Private schools were excluded from the study as it was assumed that those students in those schools may not be experiencing similar challenges like those in public schools. 


\section{Theoretical Framework}

The study was based on two theories: Shultz's Human Capital Theory and Ludwig's System Theory. According to Schultz investing in human capital through education is essential to enable graduates respond to changing opportunities [4]. Secondary schools therefore should participate in enabling students acquire knowledge, skills, and attitudes which are very crucial for human capital base. Whereas according to Ludwig a system is any pattern with elements, which are related in an efficiently constant manner with interactions of its components and

Independent Variables. nonlinearity of the interactions to validate attention. Therefore as a system the activities in the sub-county would interfere with the human capital formation to enable graduates from the schools to function amicably in the ever changing technology.

\section{Conceptual Framework}

The relationship between the independent variable and the dependent variables of the study are as shown in the figure.

\section{Process Dependent Variable \\ Process Dependent Variable}

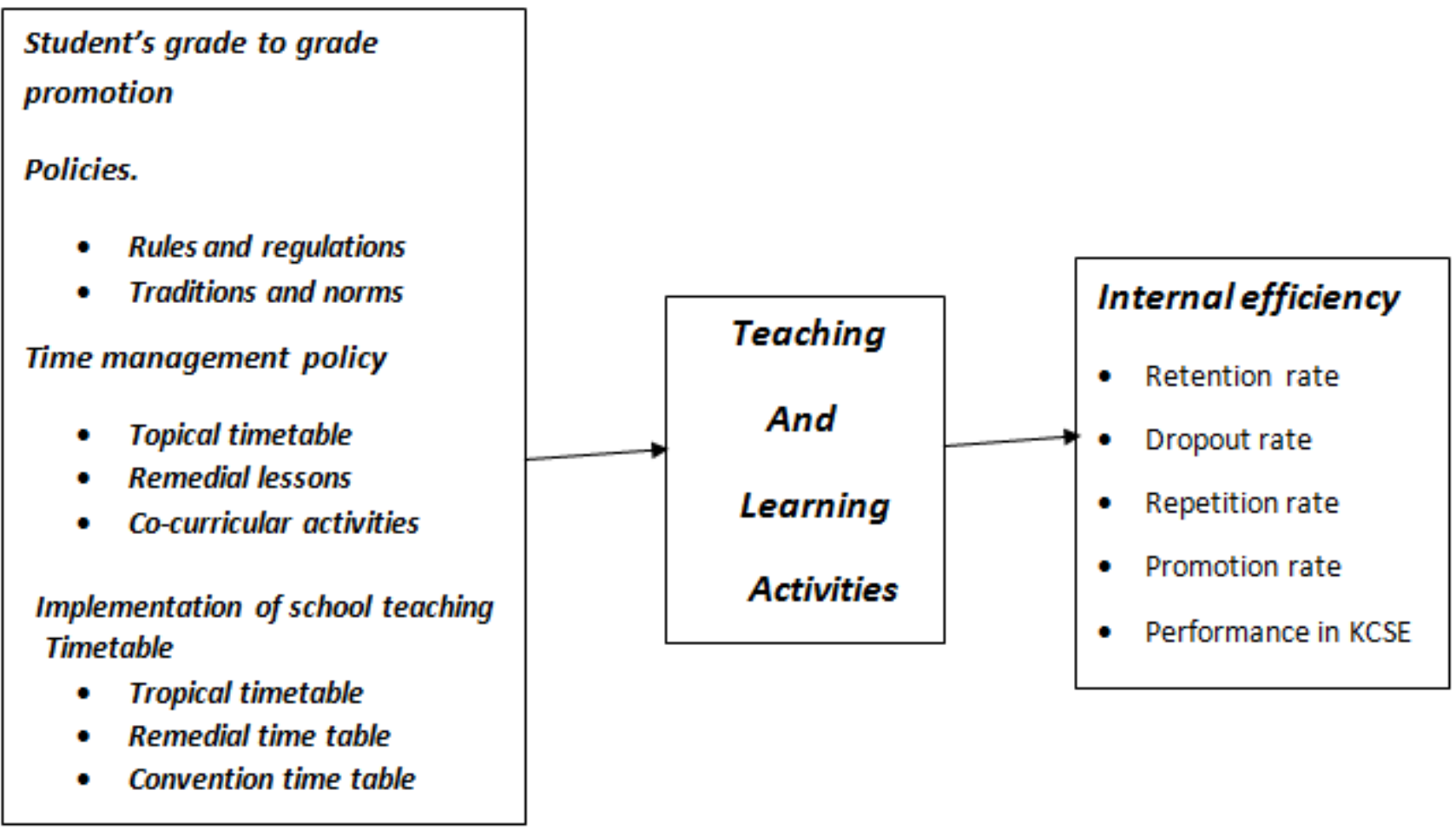

Figure 1. Relationship between factors within schools and internal efficiency

Figure 1 shows how the inputs in education are turned into output through the teaching and learning process. These independent variables include aspects of schools' policy on grade to grade promotion, time management policy and implementation of teaching timetable The interactions of these independent variables in the teachinglearning environment produces the dependent variables which are the main determinants of the internal efficiency. They include completion rate, repetition rate, dropout rate, and performance at KCSE examination.

\section{Research Design}

This study employed a descriptive survey research design. Kothari [5] asserts that the main purpose of the descriptive/diagnostic research is to determine the frequency with which something occurs or its association with something else. The researcher set out to establish the relationship between the school factors and the aspects of internal efficiency in mixed public secondary schools in Nyatike Sub County. 
staffing levels at the unit Nyatike office 2017) had been engaged translating to 109 teachers participating in this study. Fifteen Form four and fifteen Form Three students in the sampled schools were randomly selected to participate in the study. This translated to 390 students. The schools in the five divisions of Nyatike sub counties had been considered as follows. In each division the schools were chosen randomly.

Table 1. Sampling Frame

\begin{tabular}{lccc}
\hline Division & Target population & Sample & Percentage \\
\hline Nyatike Division & 15 & 3 & 28 \\
Muhuru & 6 & 2 & 11 \\
Karungu & 17 & 4 & 31 \\
Got Kochola & 8 & 2 & 15 \\
Kaler & 8 & 2 & 15 \\
\hline Total & 54 & 13 & 100 \\
\hline
\end{tabular}

The researcher used questionnaires and interviews as the instruments for gathering information. The questionnaires were used to allow respondents freedom to answer sensitive questions in the absence of the researcher. Questionnaires had both closed ended and open-ended questions to allow respondents to express and explain themselves. Lastly interviews were used to collaborate the information that was given by the students.

The collected data from the questionnaires and interviews was edited, coded and analyzed statistically using Statistical Package for Social Sciences (SPSS) version 22. The quantitative data was analyzed and tabulated using descriptive statistical tools. Tables of frequency distributions, percentages, and graphs were used. This was based on the notion that frequencies and percentages are more convenient in giving the general view of the problem making it easier to make conclusions and recommendations. Whereas tables are easier to interpret [7].

\section{Data Analysis, Interpretations and Discussion}

\subsection{Questionnaire Return Rate}

A total of 512 questionnaires were issued to the sampled schools. the questionnaires comprised of 13 to the principals, 109 for the teachers and 390 for the students. All the principals, 105 teachers and 381 students filled and returned the questionnaire giving an average of 97.5 return rate. This was deemed adequate for the study as according to Mugenda and Mugenda [6], a 50 percent and above return rate is sufficient for data analysis and interpretation.

\subsection{Demographic Information of Principals}

The demographic information provides an insight on the experience of the administrators, gender and the time they have taken in their various stations. This has a bearing on how the students perceive their role models e.g. schools headed by madam teachers offer an encouragement to girls who in turn work hard to achieve good grades by the end of the year. The time an institutional head has taken in a school determines how he understands the challenges and threats to the students' wellbeing within that niche.

The demographic information on principals was based on gender, and teaching experience as a principal and this is shown in Table 2.

Table 2. Responses of principals by gender

\begin{tabular}{ccc}
\hline Gender & Frequency & Percentage \\
\hline Male & 10 & 76.92 \\
Female & 3 & 23.08 \\
\hline Total & $\mathbf{1 3}$ & $\mathbf{1 0 0}$ \\
\hline
\end{tabular}

From values in Table 2, it is observed that 10 schools making a percentage of 76.9 were headed by male principals, among the schools visited. This can pose a challenge to the female students who may lack someone to look up to in the name of a role model and therefore could have low motivation to excel. However during the interview it was established that a majority of the schools had female teachers as deputies.

Asked to indicate the number of years they have taken in their stations, the responses are shown in Table 3.

Table 3. Number of years the principals have taken in their stations

\begin{tabular}{lcc}
\hline Years & Frequency & Percentage \\
\hline $0-3$ & 4 & 30.8 \\
$4-5$ & 5 & 38.5 \\
$6-10$ & 3 & 23.1 \\
Over 10 & 1 & 7.7 \\
\hline Total & 13 & 100
\end{tabular}

Table 3 shows that the majority of the principals at 69.3 percent in the sampled schools had stayed in their current stations for four years and above. This is good for managerial and financial stability, established cooperation with the parents and guardians, hence better knowledge of students' background to make workable policies to assist students to remain in the education system without dropping out.

\subsection{Demographic Information of Classroom Teachers}

The day to day management of student affairs is in the hands of class teachers in most of the schools. it therefore imperative to establish the bio data of the teachers too. The demographic information of classroom teachers was based on gender, professional training and years they have been teaching in their respective stations of service. Table 4 gives information on the gender of the class teachers involved in the study.

Table 4. Gender of class teachers

\begin{tabular}{ccc}
\hline Gender & Frequency & Percentage \\
\hline Male & 74 & 70.5 \\
Female & 31 & 29.5 \\
\hline Total & $\mathbf{1 0 5}$ & $\mathbf{1 0 0}$ \\
\hline
\end{tabular}


Table 4 shows that in the sampled schools the majority of the teachers were male at 70.5 percent. This could disadvantage the girl child who may want to share private information with female teachers and if not addressed well, it can contribute to girls dropping out of school. Guidance and counseling might also not be easily accessible by the girls since there are fewer female teachers who understand them better. This was confirmed from the population levels of girls and boys in the schools. Out of the 381 students interviewed, only 178 or 38.9 percent were girls.

The teachers' response on their professional training is tabulated below in Table 5

Table 5. Teachers' response on professional training

\begin{tabular}{ccc}
\hline Acquisition of professional training & Frequency & Percentage \\
\hline Yes & 89 & 84.8 \\
No & 16 & 15.2 \\
\hline Total & $\mathbf{1 0 5}$ & $\mathbf{1 0 0}$ \\
\hline
\end{tabular}

Table 5 indicates that the majority of the teachers 84.8 percent had received the professional training. It must be understood that well trained teachers have got skill abilities to handle students in class and easily help them to resolve their mental emotions that can affect them academically as postulated by Gibbons et al., [8] who said that teachers' academic level, experience, and professionalism are directly related to student achievement. To improve students' academic performance teachers must be given the right pedagogical skills matched with experience attained over the years of classroom experience.

The teachers' response on years of teaching in their respective work stations is tabulated in Table 6.

Table 6. Teachers' response on their stay in their work stations

\begin{tabular}{ccc}
\hline Length of stay & Frequency & Percentage \\
\hline $0-2$ & 23 & 21.90 \\
$3-5$ & 44 & 41.90 \\
$6-10$ & 35 & 29.53 \\
Over 10 & 07 & 6.67 \\
\hline Total & $\mathbf{1 0 5}$ & $\mathbf{1 0 0}$ \\
\hline
\end{tabular}

Table 6 shows that the majority of the teachers at 78.1 percent have stayed in their work stations for a period of three years and above. This period is good for classroom experience and understanding of individual students' challenges to some large extent. Students are the direct beneficiaries of experienced teachers who have got different methodological approaches to handle different concepts, bringing good learning environment and individual counseling.

Teachers who have stayed in the service for long tend to have a good mastery of the content, have ability to master how to deal with individual differences among students. This makes each and every learner value his studies because they make students realize their self-worth and being valued to learn.

\subsection{Demographic Information of Students}

The student demographics help us understand their age composition, gender to determine the ratio of boys to girls accessing education within the sub county and determine areas of gaps that need to be addressed. Table 7 shows brackets of the students in the study.

Table 7. Age brackets of the Form Three and Form Four students

\begin{tabular}{ccc}
\hline Age of students & Frequency & Percentage \\
\hline $17-19$ & 286 & 75.07 \\
$20-25$ & 85 & 22.31 \\
Above 25 & 10 & 2.62 \\
\hline Total & $\mathbf{3 8 1}$ & $\mathbf{1 0 0}$ \\
\hline
\end{tabular}

Table 7 indicates that the majority of students 75.1 percent, in form three and four in the sampled schools are in the age bracket of 17-19 years. Based on the government policy of enrolling children in class one at six years, it would be expected that those in form three and four are of age below or at 18 years. The data collected would suggest that most of the students are old for their respective classes. It should also be noted that there were those in the age bracket of 20 years and above who were still in high school. During the interview with the students it was established that a majority of them repeated several classes in primary schools because they could not raise the schools' required pass mark for promotion to the next classes.

Influence of student grade to grade promotion policy on internal efficiency in mixed public secondary schools in Nyatike sub-county

The first objective of the study was to examine the influence of the policy of student grade to grade promotion on internal efficiency in mixed public secondary schools in Nyatike sub-county. The ministry of education's policy is for students to transit from one grade to another without repeating. This means that students should take twelve years in primary and secondary schools for example, upon entry to class one in say 2007, a student is expected to be in form four in the year 2020. It was therefore to find out from the respondents if the policy is adhered to in the schools. Data on this is captured and presented in the following tables.

Teachers were asked for their opinion on how students are promoted from one grade to another in their schools. Their responses are illustrated in Table 8.

Table 8. Teachers' response on learners' promotion being pegged on exams

\begin{tabular}{lcc}
\hline Extent of response & Frequency & Percentage \\
\hline Strongly agree & 74 & 62.71 \\
Agree & 28 & 23.73 \\
Undecided & 12 & 10.17 \\
Disagree & 4 & 3.39 \\
\hline Total & 118 & 100 \\
\hline
\end{tabular}

The responses captured in Table 8 depict that the majority of the teachers 86.4 percent were of the opinion that promotions of students is determined by their performance in examinations. this finding seem to agree with those of Warren [9] who found in his study that exams play a major role in promotion of learners in learning institutions especially at lower grades or levels. From the responses of the students, it also emerged that 90 percent of them agreed that students are promoted based on examination results and only 10 percent were of a different opinion. During the interviews with students it 
was further established that schools have internal policies on promotion pegged on a pass mark.

Teachers were further asked for their opinion on how the internal policy on promotion affects the students. Their opinions were on whether they agree that the policy causes students to dropout or not. Their opinions showed that out of the total 118 teachers who responded, 75.4 percent agreed with the assertion that it led to many students dropping out of school while only 24.6 said it did not. Respondents who agreed with the assertion were of the opinion that no student likes to repeat a class and when compelled by the rules, many of them will opt to leave school and join fishing or gold mining activities in the sub-county as expressed in the interviews. The finding agrees with Ndaruhutse [10] findings on repetition of pupils in primary schools in Sub Saharan Africa who found out that forced repetition de-motivated learners and lead to drop outs. It should be noted that when these students repeat, they waste government resources by being allocated these resources more than ones and denying others a chance to study due to congestions.

To collaborate the information on effects of forced repetition, students were asked if they new anybody who had dropped out school from their classes. The responses from students to indicate the number of students that have dropped out since their form one was as follows.

Table 9. Dropout rates from form one

\begin{tabular}{|c|c|c|c|c|c|}
\hline Students & Frequency & $\%$ & $\mathbf{x}$ & $f x$ & $f x^{2}$ \\
\hline $0-9$ & 73 & 19.16 & 4.5 & 328.5 & 1478.25 \\
\hline $10-19$ & 265 & 69.55 & 14.5 & 3842.5 & 55716.25 \\
\hline $20-29$ & 33 & 8.66 & 24.5 & 709.5 & 19808.25 \\
\hline $30-39$ & 10 & 2.63 & 34.5 & 345.0 & 11902.5 \\
\hline Total & 381 & 100 & & 5225.5 & 88905.25 \\
\hline
\end{tabular}

Table 9 shows data on the number of students that dropped out of school since form one. From the table it can be observed that more than 300 students making more than 80 percent of the respondents knew at least ten or more students who had dropped out. The mean dropout rates and the standard deviation of the dropout rates of students in the schools within Nyatike Sub County are calculated and found as;

Mean dropout rate in the sampled schools (both in form 3 and 4)

$$
\sum \mathrm{fx} / \sum \mathrm{f}=5225.5 / 381=13.7 .
$$

This means that on average from both form three and form four classes in the sampled schools, fourteen students had dropped out since their enrolment in form one.

Standard deviation is $\sqrt{ }\left\{\left(\sum \mathrm{fx}^{2} \div \sum \mathrm{f}\right)-\left(\sum \mathrm{fx} \div \sum \mathrm{f}\right)^{2}\right\}$

$\sqrt{ }\left\{\left(\sum 88905.25 \div 381\right)-(5225.5 / 381)^{2}\right\}=6.7$.

Thus dropouts in the schools is evenly distributed at 6.7.

It was interesting when students were asked how many years they had themselves spend in school since class one in primary school. The data obtained is tabulated in Table 10 and Table 11.

Table 10. Distribution of students' total years in school since class one as at form three

\begin{tabular}{|c|c|c|c|}
\hline $\begin{array}{c}\text { No. of } \\
\text { students }\end{array}$ & $\begin{array}{c}\text { Years } \\
\text { repeated }\end{array}$ & $\begin{array}{c}\text { Duration for } \\
\text { each }\end{array}$ & $\begin{array}{c}\text { Total years } \\
\text { taken }\end{array}$ \\
\hline 20 & 1 & 12 & 240 \\
\hline 33 & 2 & 13 & 429 \\
\hline 57 & 3 & 14 & 798 \\
\hline 58 & 4 & 15 & 870 \\
\hline 29 & 5 & 16 & 464 \\
\hline 13 & 6 & 17 & 221 \\
\hline 210 & & 2310 & 3022 \\
\hline
\end{tabular}

From the data in Table 10, it can be observed that all the students in form three during the study had repeated at least ones along their course of study. Most of the students had repeated for four years. Thus at form three if they had not repeated along the way it was expected that they would have spend 11 years in school. However from the data the least number of years spend were 12 and the highest as 17 years. The average years of schooling for the form threes in the sub-county are given as; 3022/210 = 14.4 years.

From the average years of schooling value it means that a course of 11 years students have taken 14.4 years. There is therefore wastage in the system with an inefficiency index of; $3022 / 2310=1.3$.

Table 11. Distribution of students' total years in school since class one as at form four

\begin{tabular}{|c|c|c|c|}
\hline $\begin{array}{c}\text { No. of } \\
\text { students }\end{array}$ & $\begin{array}{c}\text { Years } \\
\text { repeated }\end{array}$ & $\begin{array}{c}\text { Duration for } \\
\text { each }\end{array}$ & $\begin{array}{c}\text { Total years } \\
\text { taken }\end{array}$ \\
\hline 15 & 1 & 13 & 195 \\
\hline 28 & 2 & 14 & 392 \\
\hline 42 & 3 & 15 & 630 \\
\hline 49 & 4 & 16 & 784 \\
\hline 26 & 5 & 17 & 442 \\
\hline 11 & 6 & 18 & 198 \\
\hline $\mathbf{1 7 1}$ & & $\mathbf{2 0 5 2}$ & $\mathbf{2 6 4 1}$ \\
\hline
\end{tabular}

From the data in Table 11 most of the students had repeated for four years in the course of their period of study since class one. Thus at form four if they had not repeated along the way it was expected that they would have spend 12 years in school. However from the data the least number of years spend were 13 and the highest as 18 years. The average years of schooling for the class form four in the sub-county are given as; 2641/171 = 15.4 years

From the average years of schooling value it means that a course of 12 years, students have spent on average 15.4 years. There is therefore wastage in the system with an inefficiency index of; 2641/2052 $=1$.3.

From the calculations in Table 10 and Table 11 the sub-county should plan its resource allocations in the schools at a ratio of $1: 1.3$. Thus for every expected one secondary school graduate in the sub-county, every resource needed should be budgeted at 130 percent rate. 
The assumption is that day secondary schools admit students from the local primary schools.

To assess how time management policy affect internal efficiency in mixed public secondary schools

The second objective of the study was to assess how time management policy affects internal efficiency in mixed public secondary schools. The ministry of education in Kenya controls the school calendar in terms of opening and closure dates and when co-curricular activities take place for both public and private schools. The schools are expected to plan their activities to conform to the ministry of education scheduled term dates and activities. The researcher looked at the management of the available time on internal efficiency in schools in Nyatike Sub County.

\subsection{Availability of Strategic Plan}

The first aspect of management of time is the preparation and execution of schools' strategic plans. A question was posed to principals whether they prepared strategic plans for their schools. The data captured is tabulated in Table 12.

Table 12. Response by principals on availability of strategic plans

\begin{tabular}{ccc}
\hline Response & Frequency & Percentage \\
\hline Yes & 4 & 30.77 \\
No & 9 & 69.23 \\
\hline Total & $\mathbf{1 3}$ & $\mathbf{1 0 0}$ \\
\hline
\end{tabular}

The data in Table 12 indicates that, the majority of the school principals 69.2 percent did not have strategic plans for their schools. This means that a majority of the schools have not worked out on how to spend the available time nor specified the objectives for their schools. it is like they operate schools on operational planning approach. Doing the things routinely every time so long us a day passes. It was interesting to note that when those who seemed to have prepared a strategic plan for their school, it came out clearly that this was the ministry of education requirement hence they only responded to this call. They said that the school activities were so congested and with limited financial resources they never followed those plans in their operations.

The school principals and class teachers were therefore asked how they operated their schools' calendar by expressing their opinions on various school activities that need time management. The responses are tabulated in Table 13.

From the data in Table 13 it is observed that the majority of the school principals and class teachers, 84.8 percent had prepared teaching timetable, 74.6 percent had prepared daily routine duty roaster and 58.5 percent indicated that they did not schedule for recovery of the lost lessons by teachers. The data further shows that most of the principals and class teachers, 29.7 percent were not sure if they had a time table for remedial teaching in their schools. The responses were expected since a time table is the basic teaching tool required by the ministry of education. The daily routine on the other hand stipulates the time the teachers are on duty supervising the schools' daily activities. The other arrangements like remedial teaching and recovery of missed lessons is the initiative of the schools to help weak students catch up and complete the syllabus respectively. In the absence of these arrangements means schools are not making an effort to assist slow learners to reach the required pass marks. This was confirmed from the responses in the interview with the students and teachers. They indicated that there is no collective effort by the schools to assist weak students. The result was that many students who did not attain the requisite pass marks dropped out of school increasing the internal inefficiency in the education system in the sub-county.

Effect of time tabling policy on internal efficiency in mixed public secondary schools

The third objective of the study was to examine the effect of the time tabling policy on internal efficiency in mixed secondary schools. Nyatike sub-county is located within the Lake Victoria region where the temperatures are extremely high from mid day to about 5 pm most of the time of the year. This has tended to affect the teaching time in the schools within the region. The schools follow special time table arrangements under tropical timetable. The researcher examined how the schools timetabling policy affected the operations in the schools.

The principals were asked the type of the time table format they use in their schools. It was established that all the schools use normal time tabling arrangement where school lessons begin at 8 am to $5 \mathrm{pm}$ with games inclusive. They said this is the ministry of education requirement though earlier on, up to late nineteen nineties, schools used to use the tropical time tabling arrangement. The researcher got interested to know how the students cope in class in the afternoon given the area experiences extremely high temperatures in the afternoon. It was established that 8 principals have made local arrangements where students go for games immediate after lunch between 2 and 4 and go back to class for teaching at 4 to 6 . The other 5 principals indicated that they follow the normal time table where classes end at 4 and students go for games between 4 and 5 .

Table 13. Principals' and class teachers' responses on time management

\begin{tabular}{|c|c|c|c|c|c|c|c|c|c|c|}
\hline \multirow{2}{*}{$\begin{array}{l}\text { Responses } \\
\text { Availability of; }\end{array}$} & \multicolumn{2}{|c|}{ Strongly agree } & \multicolumn{2}{|c|}{ Agree } & \multicolumn{2}{|c|}{ Undecided } & \multicolumn{2}{|c|}{ disagree } & \multicolumn{2}{|c|}{ Strongly disagree } \\
\hline & Freq. & percent & Freq. & percent & Freq. & percent & Freq. & percent & Freq. & Percent \\
\hline Teaching timetable & 100 & 84.8 & 18 & 15.3 & 0 & 0 & 0 & 0 & 0 & 0 \\
\hline Daily routine roaster & 88 & 74.6 & 26 & 22.0 & 4 & 3.4 & 0 & 0 & 0 & 0 \\
\hline Weekly remedial time table & 12 & 10.1 & 19 & 16.1 & 35 & 29.7 & 27 & 22.9 & 25 & 21.2 \\
\hline Schedule for recov. of lesson & 9 & 7.6 & 17 & 14.4 & 23 & 19.5 & 30 & 25.4 & 39 & 33.1 \\
\hline
\end{tabular}


Table 14. Opinions of students on coping with afternoon lessons

\begin{tabular}{|c|c|c|c|c|c|c|c|c|c|c|}
\hline Responses & \multicolumn{2}{|c|}{ Strongly agree } & \multicolumn{2}{|c|}{ Agree } & \multicolumn{2}{|c|}{ Undecided } & \multicolumn{2}{|c|}{ Disagree } & \multicolumn{2}{|c|}{ Strongly disagree } \\
\hline Students’ opinion & Freq. & percent & Freq. & percent & Freq. & percent & Freq. & percent & Freq. & Percent \\
\hline Teaching should start at 6 to 1 pm every day & 76 & 20 & 50 & 13.1 & 120 & 31.5 & 68 & 17.8 & 67 & 17.6 \\
\hline Lessons in the afternoon are wasted & 197 & 51.7 & 126 & 33.1 & 4 & 1.0 & 48 & 12.6 & 6 & 1.6 \\
\hline $\begin{array}{l}\text { Teachers most of the time don't teach in the } \\
\text { afternoon }\end{array}$ & 208 & 54.6 & 96 & 25.2 & 35 & 9.2 & 17 & 4.5 & 25 & 6.6 \\
\hline Afternoon lessons are used for remedial & 120 & 31.5 & 137 & 36.0 & 15 & 3.9 & 60 & 15.7 & 49 & 12.9 \\
\hline
\end{tabular}

It was important for the researcher to find out the feelings of the students on this arrangement of timetabling. The students were asked for their opinion on how they coped up with lessons in the afternoons. The responses are tabulated in Table 14.

From Table 14, it can be observed that students had varied opinions on the afternoon teaching. Most of the students 31.5 percent were undecided as to whether teaching should start early so that the afternoon is left free. When it came to the lessons in the afternoon being wasted the majority at strongly and agree 84.8 percent affirmed the assertion. On teachers missing lessons in the afternoon, over 90 percent of the students were of that opinion. Sixty seven point five percent of the students were of the opinion that afternoon lessons are used for remedial.

The varied opinion made the researcher want to know what students do during weekends and evenings after school. Data on this item was captured in Table 15.

Table 15. Activities students engage in during the weekend

\begin{tabular}{|l|c|c|}
\hline Activity & Frequency & Percentage \\
\hline Boda boda riding & 70 & 18.4 \\
\hline Fishing & 120 & 31.5 \\
\hline Gold mining & 90 & 23.6 \\
\hline Helping in domestic chores & 130 & 34.1 \\
\hline Studying in school & 80 & 21.0 \\
\hline Remedial teaching & 108 & 28.3 \\
\hline Visiting friends & 20 & 05.3 \\
\hline
\end{tabular}

From Table 15 it can be observed that students do not engage themselves in academic activities much during the weekend. Only 188 opinions out of 618 or 30.4 percent of the opinions expressed that they do either remedial work or study at home. This a dangerous trend given that a majority of them were over age as earlier reported. They hence end up performing poorly and prematurely dropout when they don't achieve the targeted pass marks as per the schools internal policies on promotion.

\section{Conclusions and Recommendations}

From the study findings the following conclusions are made;

1. The internal school policies on grade to grade promotion have affected greatly the internal efficiency in education in Nyatike sub-county. The inefficiency index of 1.3 was found.

2. Time management policy was being poorly implemented in the schools in the sub-county.
Schools seem to be managing the school time as a routine no extra effort is being put in to utilize time to assist weak students

3. Afternoon lessons are wasted due to adverse temperatures. Most of the lessons go un attended by the teachers hence students become bored and disoriented in learning. As a result they prematurely dropout of school to engage in other activities

Based on the findings of the study it is recommended that;

i. The sub-county director of education enforce the automatic promotion policy right from primary schools where it was found to be rampant

ii. The cabinet secretary of education should consider re-introducing the tropical time table for schools along the lake so that time is properly utilized.

\section{References}

[1] Kumar and Ahmad (2007). Meaning, Aims and Process of Education. Available from:

https://sol.du.ac.in/Courses/UG/StudyMaterial/16/Part1/ED/Englis h/SM-1.pdf.

[2] Ozturk, S.K. (2011). Investment in human capital. American Economic Review, 51 (1), Pp.334-342.

[3] Klein (2011). Psychological Research Method; a conceptual Approach. Unpublished M.Ed. Thesis. University of Bradford.

[4] Schultz, T. (1971). Investment in human capital. The role of education and research. New York: Free Press.

[5] Kothari (2004). Research methodology: Methods and Techniques. New Delhi; New age international (P) limited, publisher.

[6] Mugenda, O. M \& Mugenda, A. G. (2003). Research Methods: Qualitative and Quantitative Approaches. Nairobi: Acts Press.

[7] Orodho J. A, Khatete I and Mugiraneza J. P (2016). Concise Statistics; An Illustrative Approach to Problem Solving. Nairobi, Kanezja Happyland Enterprises.

[8] Gibbons, S., kimmel, H. \& O’Shea, M. (1997). Changing Teacher Behaviour through Staff Development: Implementing the teaching and Content Standards in Science schools and Mathematics. 976(1): 302-340.

[9] Warren F. (2014). Promotion of students' wellbeing. Paris IIEP.

[10] Ndaruhutse, S (2008). Grade repetition in primary schools in Sub-Saharan Africa: an evidence base for change. CfBT Education Trust.

[11] Cohen, D. \& Soto, M. (2007). Growth and human capital: Good data, good results: Paris school of Economics: Springer Science+Business Media, LL.

[12] Hannan Homad Mohamed Alharbi (2015). Internal and External Efficiency of the Saudi Education system.

[13] Leedy and Arnold (2005). Practical research: Planning and design; Upper Saddle River, N.J.: Prentice Hall.

[14] Lumuli, N. C. (2009). An Investigation into Internal Efficiency Measures in Promotion of Access and Completion Rates in Public secondary Schools in Bungoma, South District. Unpublished M.Ed. Thesis, University of Nairobi. Kenya.

[15] Nyatike secondary schools. 2017. KCSE analysis; performance improvement and value added progress. Sub-County Education office; Nyatike Kenya. 
[16] Orodho, J. A. (2009). Techniques of writing research proposals and reports in education and social sciences. Nairobi. Kanezja publishers.

[17] Rono, J. K. (1990). Factors Influencing the Rate of Drop out Among Primary School Students in Nandi District of Kenya. Unpublished M. Ed Thesis, Kenyatta University, Nairobi Kenya.
[18] Sanothimi, \& Bhaktapur, (2001). Study of Internal Efficiency of Primary Education. Nepal. http.//www.esat.org.np/.

[19] Teacher establishment and shortage within Nyatike sub county for the year 2017 TSC office; Nyatike sub- county. Kenya.

[20] UNESCO. (2010). Education for All. Global Monitoring Report, London. L. Publishers. 